\title{
MODELY NÁKUPNÍHO PROCESU ORGANIZACÍ PRO TŘETÍ TISÍCILETÍ
}

\section{Xenie Lukoszová}

\section{Klíčová slova:}

Nákup, proces, procesní rízení, procesní model, nákupní proces, logistika, marketing.

\section{Keywords:}

Purchasing, process, process management, process model, purchasing process, logistics, marketing.

\begin{abstract}
Abstrakt:
Cílem př́spěvku je představit aktuální modely podnikového nákupu, jejichž tvorba je založena na dostupných odborných poznatcích a identifikaci procesů v subsystému nákupu průmyslového podniku v komplexu jeho klíčových komponentů a v kontextu řízení změn vedoucích ke zlepšení efektivnosti nákupu.

Východiskem pro vytvoření procesních modelů nákupu je analýza dosud vytvořených a zveřejněných teoretických modelů nákupního procesu organizací. Následná aktualizace těchto modelů a jejich doplnění s ohledem na vývoj a konfrontaci hospodářské teorie i praxe přináší rozšíření teorie o nové modely nákupního procesu.
\end{abstract}

\begin{abstract}
:
The aim of this paper is to present the actual enterprise-purchasing models. Models creation is based on the available expertises and the identification of processes of industrial enterprisepurchasing subsystem and its keys components in the case of change management in order to increase purchasing efficiency.

The base of purchasing-process-models creation is the analyse of theoretical purchasingprocess-models of organizations, which were made and published. Subsequent models update and their supplementation due to the development and confrontation of economic theory and practice. This brings the enlargement of the theory as to new models of the purchasing process.
\end{abstract}

\section{Úvod}

Důvodem tvorby modelů podnikových nebo funkčních procesů je nejčastěji snaha o dosažení podnikových cílů v podobě zvýšení podnikové výkonnosti, či efektivnosti nebo jen zajišsění přežití podniku v krizových podmínkách. Ačkoliv je v naší podnikové praxi procesní řízení považováno za poměrně moderní směr, jeho kořeny mají daleko starší historii. Svědčí o tom také dále uvedené modely nákupního procesu.

O nákupu, jako o procesu organizace, doslova hovoří dostupná odborná literatura k problematice řízení nákupu (autoři I. Gros, J. Kita, U. Koppelmann, P. Kotler, J. Tomek, G. Tomek a další). Otázku, zdali je možné chápat nákupní rozhodování jako proces s rozdílnými dílčími etapami, si položili v roce 1967 již Robinson a Stidsen. 


\section{Klasické modely nákupního procesu organizací}

První zmínky o modelech nákupního procesu organizací se tedy v zahraniční literatuře objevují od 60 . let. $\mathrm{Z}$ existence těchto modelů lze vyvodit, že procesní prrístup k řízení nákupu je historicky odůvodněný a aplikovatelný v podmínkách podnikové reality. $\mathrm{K}$ jednotlivým subprocesům, uvedeným v těchto modelech, je možno přiřadit také osoby odpovědné za jejich průběh. Lze dospět k závěru, že tyto modely vznikly proto, aby bylo zřejmé, z kterých fází se nákup skládá, které z nich jsou klíčové, jak je správně provádět a pomocí identifikace fází nákupního procesu a revize jejich obsahu dosáhnout pozitivních změn $\mathbf{v}$ nákupu $s$ dopadem na navazující podnikové procesy a podnikový výstup.

Nákupní proces byl především předmětem zkoumání modelů 70. let, avšak ani modely 80 . let nelze z procesního pojetí zcela vyloučit, nebot' řada z nich obsahuje rovněž fáze nákupního procesu, které však modifikuje nebo $\mathrm{v}$ části výběru dodavatele rozšiřuje o další. Uvedená modifikace fází nákupního procesu je založena na realizaci marketingového výzkumu na průmyslovém trhu (tzv. induktivní proud), a proto ještě více koresponduje se současnou nákupní praxi. $\mathrm{V}$ modelech 80 . let se zároveň výrazněji objevuje pohled na nákup jako na interakční proces mezi dodavatelem a odběratelem, respektive prodejcem a nákupčím (což tvoří základ modelů interakčního proudu). Pozornost v těchto novějších modelech je soustředěna především na problém výběru dodavatele. Úvahy zformulované do podoby modelů interakčního proudu pak vedly kolem roku 1990 ke vzniku koncepce nákupního marketingu [22].

Od 90. let se také v české odborné literatuře objevuje procesní pohled na nákup. Na nákupní proces podniku lze podle J. Tomka nahlížet dvojím způsobem, a to v širším a užším pojetí. Nákupní proces $\mathbf{v}$ užším pojetí představuje pouze proces rozhodování o nákupu z pohledu odběratele. Toto pojetí můžeme označit za značně zúžené, nebot' nákupní proces musí být kromě samotného rozhodování o nákupu nutně doprovázen zmiňovanými interakčními vazbami a logistickými, popřípadě dalšími aktivitami. Podnikový nákupní proces v užším pojetí lze vyjádřit pomocí následujícího modelu, uvedeného na obr. 1: Podnikový nákupní proces v užším pojetí.

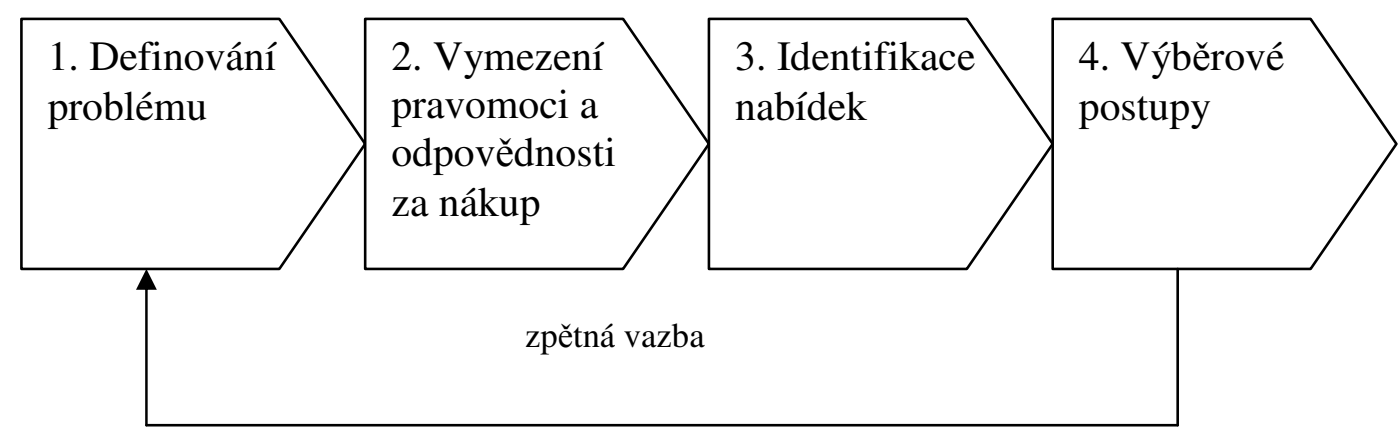

Obr. 1: Podnikový nákupní proces v užším pojetí

Pramen: Upraveno podle [23, s. 75]

Nákupní proces v širším pojetí (proces opatřování) lze podle G. Tomka a J. Tomka vyjádřit následujícím obr. 2: Nákupní proces v širším pojetí. 


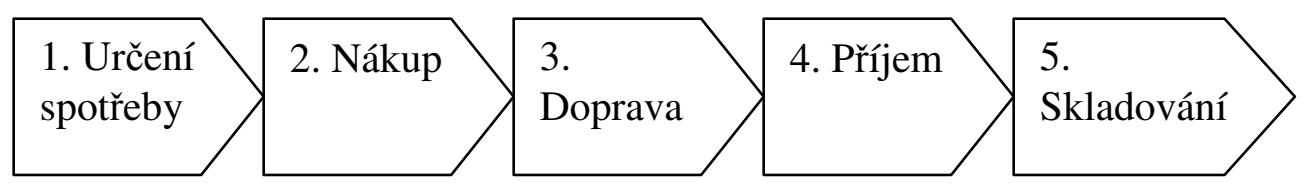

Obr. 2: Nákupní proces v širším pojetí

Pramen: [24, s. 19]

Nákupní proces v širším pojetí (proces opatřování) je rozšîren o fáze logistické povahy (tj. takové, které umožňují realizaci hmotných toků na vstupu do podniku). Proto, aby mohly být realizovány úkoly nákupu a bylo tak dosahováno strategických cílů nákupu (v souladu se strategickými cíli podniku), musí v nich probíhat hmotné a s nimi spojené informační procesy. Lze tedy vyvodit, že doprava (pokud je realizována odběratelem), příjem a skladování tvoří důležitou součást procesů podnikového nákupu. L. Pražská a J. Jindra [12, s. 344] k problematice logistických a informačních procesů uvádějí: „Tyto procesy představují dynamiku, fungování celého systému.“ Jejich obsah lze podle těchto autorů vymezit $\mathrm{v}$ rovině:

a) věcné, např. nákup, doprava, skladování;

b) řídící, kdy se jedná o procesy plánování, organizování, koordinace a kontroly nákupu.

Z poznatků uvedených $\mathrm{v}$ interních materiálech poradenských fïrem je možno vyvodit, že $\mathrm{v}$ průmyslovém podniku představují klíčové vstupy a výstupy procesu nákup skutečnosti uvedené na obr. 3: Klíčové vstupy a výstupy procesu nákup.

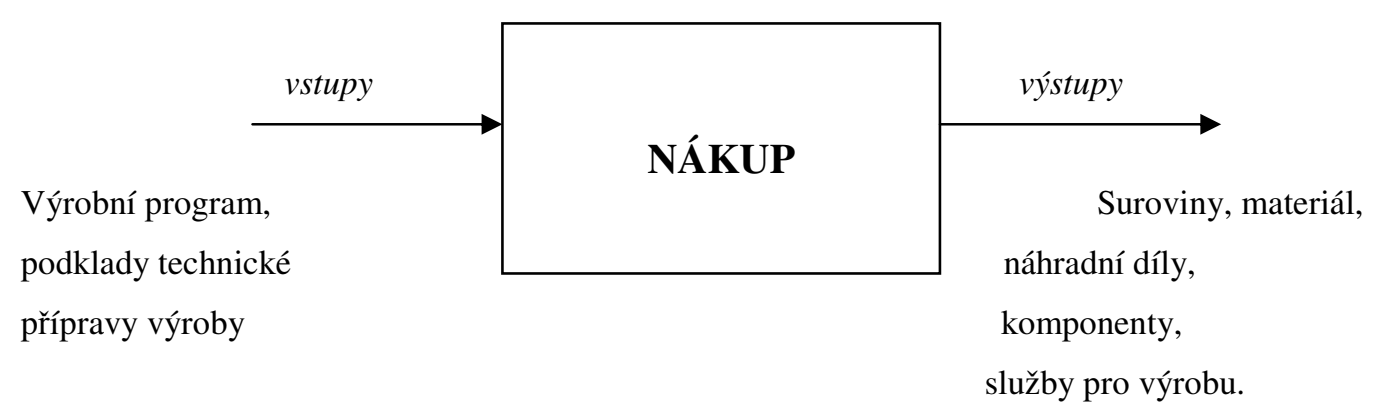

Obr. 3: Klíčové vstupy a výstupy procesu nákup

Pramen: vlastní zpracování

Hlavní výstupy procesy nákupu jsou v průmyslovém podniku vstupem do procesu výroby a uspokojují potřeby interních zákazníků.

Z dostupné odborné tuzemské i zahraniční literatury lze dále dedukovat, že proces nákupu zahrnuje řadu komponentů, tzv. subprocesů. Jejich výčet se však liší s ohledem na vymezení obsahu nákupního procesu v konkrétním podniku. Již z teoretických východisek je zřejmé různé pojetí obsahu nákupního procesu. V odborné literatuře, jak je ostatně uvedeno dříve, je rozlišován např́íklad nákupní proces $\mathrm{v}$ užším pojetí a nákupní proces $\mathrm{v}$ širším pojetí a řada alternativních kategorií s obdobným významem. 


\section{Model interakcí s jinými podnikovými procesy}

Změny $\mathrm{v}$ podniku, at' už zásadní více či méně, musí být prioritně zaměřeny do oblasti základních podnikových procesů, kterými podle M. E. Portera rozumíme především zásobovací logistiku, výrobu, prodej a distribuci, jež se vzájemně ovlivňují. (Nákup, výroba a prodej zároveň představují základní logistické subsystémy průmyslového podniku, kterými probíhá hmotný tok nebo též tradiční základní podnikové funkce.) Mezi podnikové procesy lze zařadit také další průřrezové podnikové aktivity jako je marketing, informatika, logistika, finance, skladování, administrativa, personalistika (jenž tvoří základ procesního pohledu na podnik). V následující tabulce 1: Umístění podnikových procesů v logistických subsystémech podniku jsou uvedeny hlavní interakce procesu nákup s jinými podnikovými procesy.

\begin{tabular}{|l|l|}
\hline Podnikové procesy & Poloha v logistickém subsystému podniku \\
\hline Nákup & Nákup \\
\hline Výroba & Výroba \\
\hline Prodej & Prodej \\
\hline Marketing & Prodej, výroba, nákup \\
\hline Informatika & Prodej, výroba, nákup \\
\hline Logistika & Nákup, výroba, prodej \\
\hline Finance & Nákup, výroba, prodej \\
\hline Skladování & Nákup, výroba, prodej \\
\hline Administrativa & Nákup, výroba, prodej \\
\hline Personalistika & Nákup, výroba, prodej \\
\hline
\end{tabular}

Tab. 1: Umístění podnikových procesů v logistických subsystémech podniku

Pramen: vlastní zpracování

Z uvedené tabulky 1 je zřejmé, že nákup jako logistický subsystém podniku (a zároveň základní podniková funkce) představuje v pojetí procesního řízení také podnikový proces. S procesem nákupu jsou pak v nejvýznamnějších interakcích procesy marketingu, informatiky, logistiky, financí, skladování, administrativy a personalistiky, které jsou nezbytné pro zdárné fungování podnikového nákupu i organizace jako celku. Zejména těmto procesům musí být při realizaci a zlepšování nákupu věnována v podniku klíčová pozornost. V průmyslovém podniku výstup z procesu nákup představuje vstup do všech ostatních podnikových procesů, především pak do procesu výroby. V obchodním podniku je situace obdobná s tím, že prioritně navazujícím je prodej, dále jsou výstupy nákupu rovněž určeny pro zabezpečení chodu ostatních (pomocných, obslužných, řídících) procesů organizace.

Interakce procesů v podnikovém nákupu (včetně jejich nejdůležitějších výstupů do procesu nákupu a skladování, s nímž je často v praxi spojován) je schematicky znázorněna pomocí obr. 4: Procesy v podnikovém nákupu. 


\section{MARKETING LOGISTIKA INFORMATIKA}

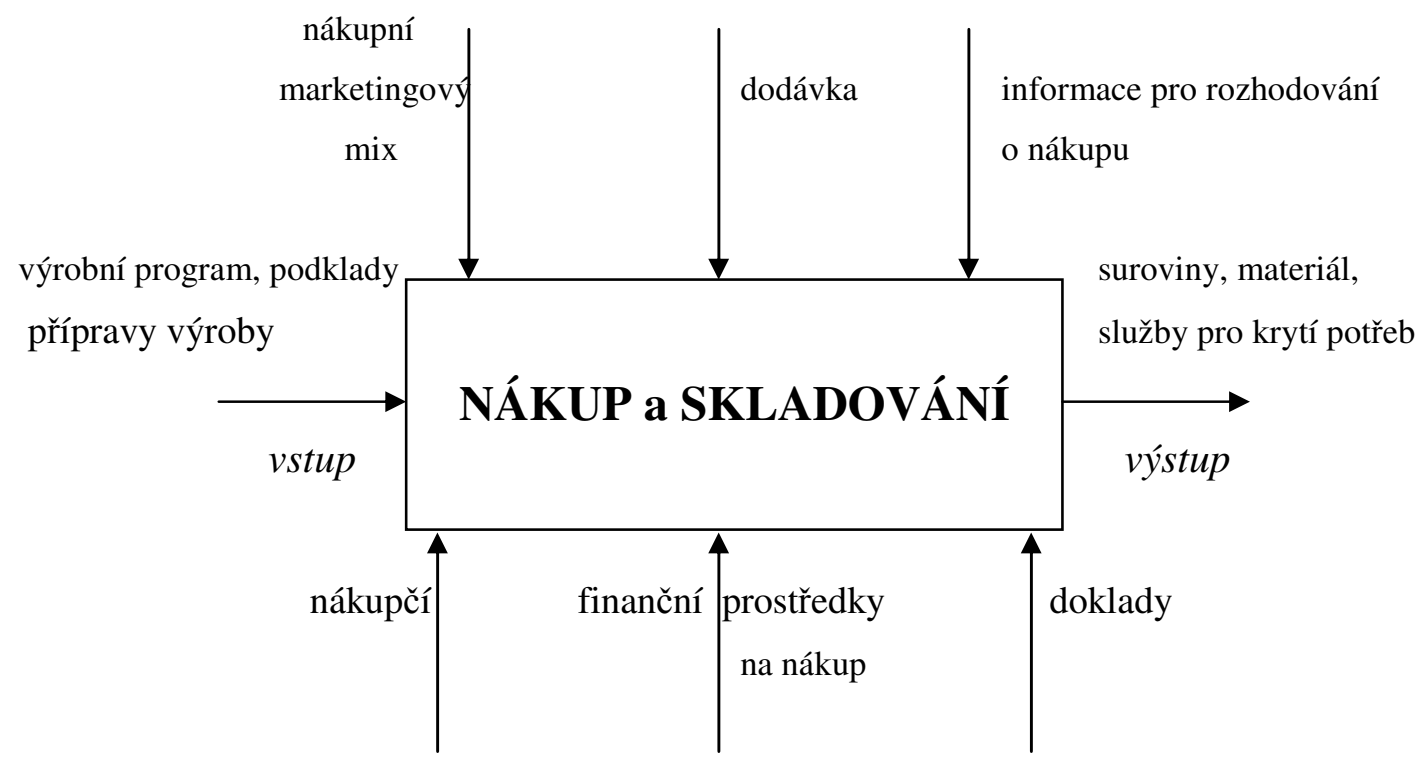

PERSONALISTIKA

FINANCE

ADMINISTRATIVA

Obr. 4: Procesy v podnikovém nákupu

Pramen: vlastní zpracování

\section{Model subprocesů $\mathbf{v}$ podnikovém nákupu}

Jedním z častých praktických požadavků managementu podniku při realizaci změny na vstupu je rozdělení podnikových procesů na proces nákupu a proces skladování (jako objektu řízení změny). Tento přístup mimo jiné již dříve respektovala také dokumentace certifikovaného systému řízení jakosti podle normy ČSN EN ISO 9001:1996 a 9001:2001, dnes je tato základní norma pro certifikaci systému řízení jakosti organizace aktualizována do podoby ČSN EN ISO 9001:2009.

Podle dokumentace zmíněné normy ISO 9001 se proces nákupu materiálů, výrobků a služeb skládá z definování požadavků na materiály, výrobky a služby, které zahrnují:

a) specifikaci požadavku;

b) předložení podmínek dodavateli ve smlouvě o budoucí smlouvě;

c) výběr dodavatele;

d) návrh kupní smlouvy;

e) kupní smlouvu.

Dále pak podle této normy do procesu nákupu patří odběr a př́ijem na sklad, který se skládá z:

a) odběru dodávky;

b) vstupní kontroly dodaného zboží nebo služby;

c) rozhodování o shodě, resp. neshodě;

d) př́ijmu na sklad, vedení dokumentace.

Znamená to, že při respektování této normy by se pak v podnikovém nákupu neoddělitelně realizovaly dva procesy: proces nákupu a proces skladování. Všechny uvedené subprocesy jsou elementárními objekty pro praktickou realizaci změn nákupního procesu. 
Do procesu podnikového nákupu tedy na základě globálních norem ISO řady 9000 chronologicky řadíme zejména tyto klíčové subprocesy:

- vznik a specifikaci nákupních požadavků;

- průzkum nákupního trhu;

- výběr dodavatele;

- uzavírání kupních smluv;

- vyřizování objednávek.

Proces skladování na podnikovém vstupu (který, jak je již dříve uvedeno, v širším pojetí rovněž do nákupního procesu patří) je reprezentován především následujícími subprocesy:

- př́jem materiálu na sklad;

- vstupní kontrola;

- udržování a péče o zásoby;

- výdej materiálu ze skladu.

V̌̌echny uvedené subprocesy jsou elementárními objekty pro praktickou realizaci změn. V logistickém subsystému nákupu a skladování v podniku se objevují interakce (jak vyplývá z tabulky 1: Umístění podnikových procesů $\mathrm{v}$ logistických subsystémech podniku) zejména $\mathrm{s}$ procesy (jakožto průřezovými činnostmi) marketingu, logistiky, financí informatiky, personalistiky a administrativy.

Procesy, které jsou s nákupem v nejdůležitějších interakcích je zapotřebí chápat především jako složky technického subsystému podniku, které je nutno v dynamických systémech za účelem zachování konkurenční schopnosti vystavit cíleným změnám.

Druhou částí podnikového systému je sociální subsystém, který v prř́padě nákupu znamená „energetizaci“ pracovníků nákupu (tzn. managementu nákupu, nákupčích), dále pak pracovníků skladového hospodářství (skladového managementu, skladníků, popř́ípadě analytiků a kontrolorů zásob). V rámci procesu řízení změn je zapotřebí aktivovat v první řadě sociální subsystém, to znamená ty pracovníky, kteří jsou odpovědni za konkrétní proces, a proto také do určité míry participují na změnách v technickém subsystému podniku.

V procesech nákupu a skladování je možno přistoupit ke změnám po linii jejich subprocesů. Typické subprocesy, které budou podléhat revizi a cíleným změnám, jsou uvedeny $\mathrm{v}$ následující tab. 2: Subprocesy podnikového nákupu.

\begin{tabular}{|l|l|}
\hline Procesy nákupu & Subprocesy nákupu \\
\hline Nákup & $\begin{array}{l}\text { Stanovení nákupních potřeb, komunikace a obchodní } \\
\text { jednání s dodavateli. }\end{array}$ \\
\hline Skladování & $\begin{array}{l}\text { Př́iem zásob, manipulace se zásobami, výdej zásob, } \\
\text { likvidace nepotřebných zásob. }\end{array}$ \\
\hline Marketing & $\begin{array}{l}\text { Tržní analýzy, analýza konkurence, průzkum } \\
\text { dodavatelù, výběr dodavatelù. }\end{array}$ \\
\hline Logistika & Doprava, řízení zásob, vy̌rizování objednávek. \\
\hline Finance & $\begin{array}{l}\text { Př́idělování a zabezpečení finančních prostředků na } \\
\text { nákup. }\end{array}$ \\
\hline Informatika & $\begin{array}{l}\text { Evidence zásob, zpracování informací o nákupu do } \\
\text { informačního systému. }\end{array}$ \\
\hline Personalistika & Výběr a řízení pracovníků nákupu. \\
\hline Administrativa & $\begin{array}{l}\text { Vystavení skladové karty, objednávky, kupní } \\
\text { smlouvy, pŕíjemky, výdejky. }\end{array}$ \\
\hline
\end{tabular}

Tab. 2: Subprocesy podnikového nákupu

Pramen: vlastní zpracování 
Obsah výše uvedených procesů však nelze zcela zobecnit, protože se liší s ohledem na podmínky konkrétního podniku, jako jsou jeho velikost, obor, rozsah hmotného toku apod. a je podmíněn přjatou organizační strukturou podniku (tzn. vymezením hierarchických vztahů, pravomocí a odpovědností pracovníků za nákup). Definování procesů v podniku je věcí managementu, tzv. rady změn. Za vymezení hranic procesu nákupu, jeho poslání, interakcí a jednotlivých subprocesů odpovídá v podniku manažer změn neboli tak zvaný vlastník procesu nákup. Z tohoto důvodu proces skladování, který zde vystupuje jako samostatný podnikový proces $\mathrm{v}$ nákupu, bývá někdy $\mathrm{v}$ podnicích považován za součást procesu nákup nebo logistika (s praktickým dopadem na jeho začlenění do organizační struktury).

\section{Model administrativy nákupního procesu}

Pro snadnější pochopení administrativních procesů souvisejících s nákupem zboží a po konzultaci s praktiky (nákupci a účetními) byl vytvořen model administrativy nákupního procesu, který je znázorněn na obr. 5: Administrativní proces v nákupu.

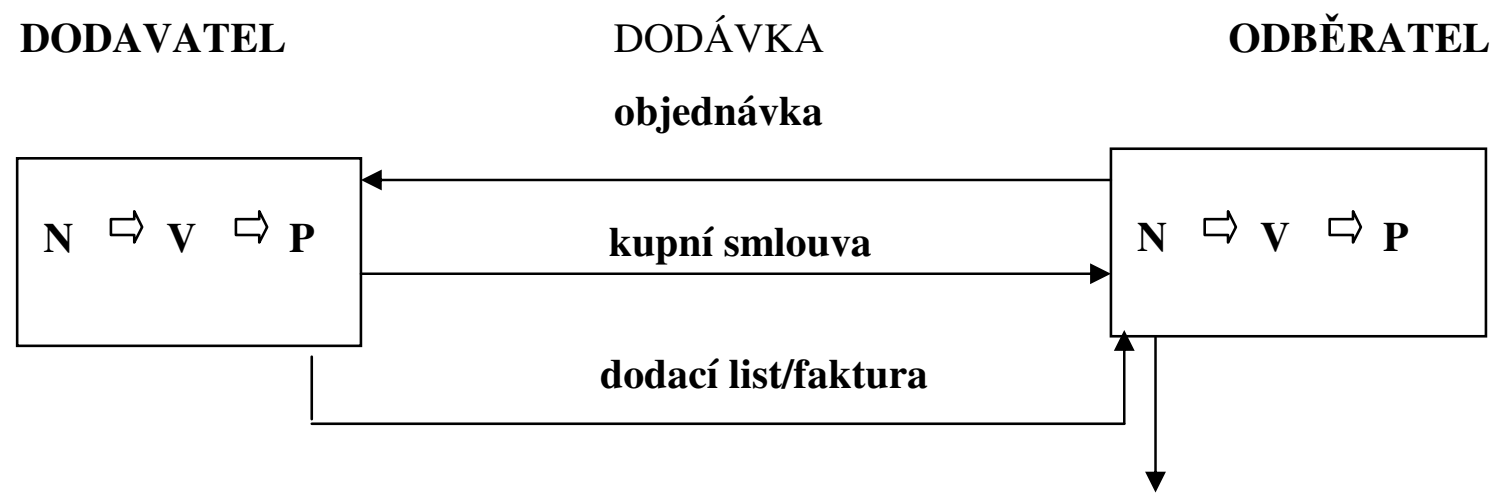

SKLAD

dodací list

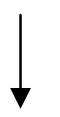

př́íjemka zboží
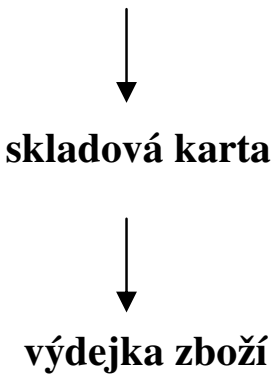

Obr. 5: Administrativní proces v nákupu

Pramen: vlastní zpracování, publikováno [12, s. 92]

\section{Model prvků a vazeb v procesech podnikového nákupu}

Charakteristické prvky a vazby v procesech podnikového nákupu, které mají zásadní vliv na dosažení vymezených cílů, jsou uvedeny na obr. 6: Prvky a vazby v procesech nákupu. 


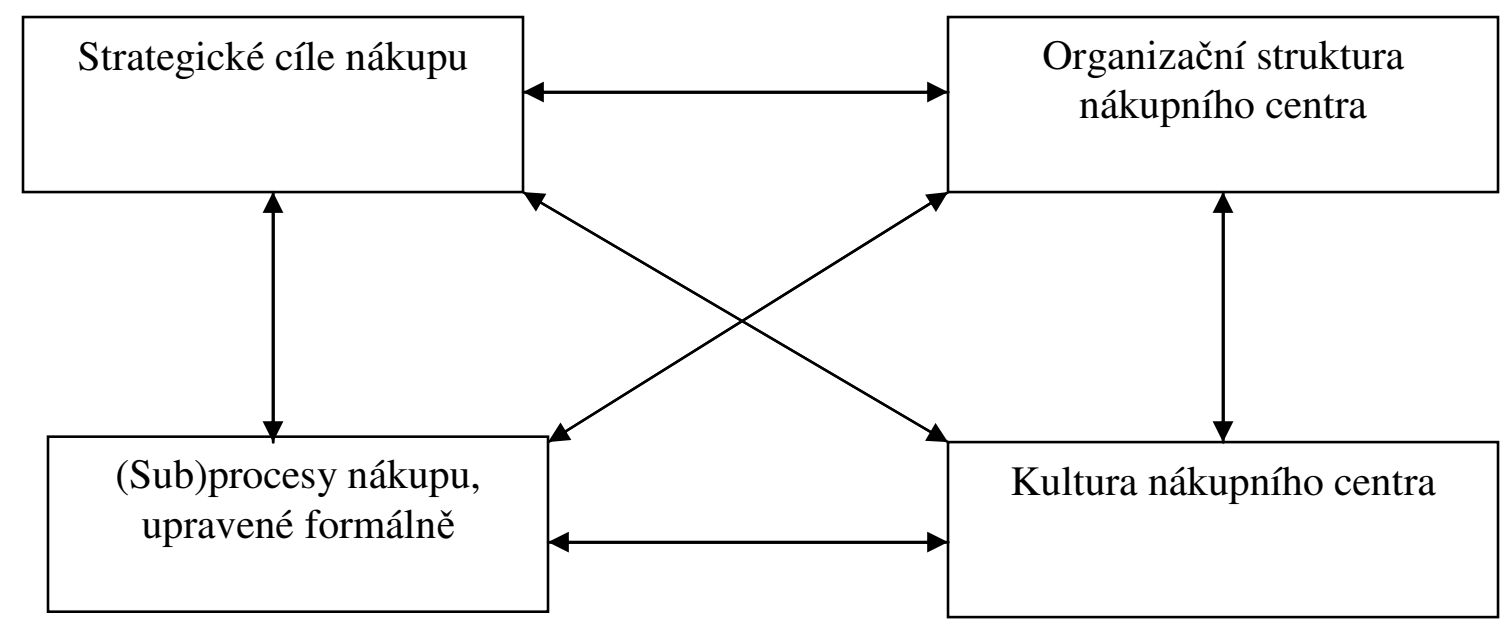

Obr. 6: Prvky a vazby v procesech nákupu

Pramen: vlastní zpracování, podle [21, s. 347]

Strategické cíle, organizační strukturu a formální pravidla nákupu současná literatura z oblasti managementu označuje jako tvrdé prvky. K tomu, aby však mohly procesy podnikového nákupu zdárně probíhat, je zapotřebí také analyzovat a zlepšovat tzv. měkké prvky - kulturu nákupního centra, která je dána hodnotami a postoji jejich členů, které vedou k určitému chování. Efektivnost nákupu je však dále podmíněna souladem interních faktorů (tvrdých a měkkých prvků) s faktory externími, tedy se situací ve vnějším podnikatelském prostředí a v daném oboru podnikání.

\section{Závěr}

Procesní řízení nákupu představuje integrální součást procesního řízení podniku. Uplatnění procesního přístupu je $\mathrm{v}$ současné době zvláště typické $\mathrm{v}$ podnikatelské sféře, kde nákup bezesporu patří ke strategickým činnostem, ale celá řada zkušenosti poradenských firem ukazuje, že jej lze s úspěchem aplikovat i do veřejné sféry.

Závěrem lze konstatovat, že procesní přístup k řízení nákupu není zcela novým momentem, ale teprve v poslední době se systematičtěji rozvinulo jeho odborné zázemí, a to v důsledku změn tržního prostředí. Důkazem existence teorie procesního přístupu k řízení nákupu jsou zejména klasické modely nákupního procesu ze 70 . let minulého století a jejich další rozpracování v podobě induktivního proudu modelů 80 . let. Uvedený závěr však skutečně platí v teoretické rovině, v rovině praktické (aplikační) a zvláště pak v podmínkách středoevropských ekonomik představuje procesní řízení poměrně nový směr vývoje managementu. Na světovou scénu procesní management vstupuje na př̀lomu druhého a třetího tisíciletí (jak je uvedeno v teorii T. Kuhna z roku 1997), i když o prvních náznacích jeho praktické realizace lze uvažovat již v souvislosti s H. Fordem, který rozložil proces montáže automobilů na posloupnost jednotlivých činností a tímto aplikoval teorii významného představitele klasické ekonomie A. Smithe, autora proslulého knihou O původu bohatství národů (z roku 1776), v níž se objevuje názor, že většina podniků je budována na principu dělby práce a smyslem této dělby je rozložení procesů průmyslové výroby na co nejjednodušší základní úkoly.

Základním důvodem vedoucím podnikatelské subjekty ke snahám o důslednou implementaci procesního řízení je přitom zvýšení intenzity konkurence a úsilí o zajištění 
konkurenceschopnosti podniku na národním, zahraničních, mezinárodních i globálních trzích. Tuto skutečnost dále umocňuje nutnost se stále více přizpůsobit individuálním požadavkům zákazníka, což poněkud vytěsňuje dřívější rozměry hromadné výroby a tím také v této původní situaci vhodné funkční řízení. Možnou cestou, jak zajistit dlouhodobou prosperitu podniků, se ukázalo procesní řízení. Zejména tam, kde jsou podnikové procesy obsáhlé a složité, je zapotřebí hledat cesty jejich zprůhlednění, které by vedly ke zvýšení celkové efektivity podniku. Aktuálním nástrojem pro zprůhlednění podnikového nákupu v současných podmínkách je uplatnění procesních modelů zohledňujících interakce nejen s jinými vnitropodnikovými procesy, ale také s dalšími prvky dodavatelského řetězce.

Právě od kvalitního zvládnutí průběhu všech procesů podnikového nákupu se odvíjí nákladové, kvalitativní i časové předpoklady konkurenční schopnosti podniku, které mají za následek jeho dlouhodobou prosperitu.

\section{Literatura:}

[1] CHRISTOPHER, M. Logistika v marketingu. Přel. Prokeš, R., 1. vydání. Praha: Management Press, 2000. 166 s., ISBN 80-7261-007-4

[2] GAŠPARÍK, J. Manažérstvo kvality v stavebníctve. 2. vydání. Bratislava: Jagagroup, 2000. 174 s., ISBN 80-88905-13-3

[3] HAMMER, M., CHAMPY, J. Reengineering - radikální proměna firmy, manifest revoluce v podnikání. 3. vydání. Praha: Management Press, 2000. 212 s., ISBN 807261-028-7

[4] KAPLAN, R. S., NORTON, D. P. Balanced scorecard. Přel. Šusta, M., 1. vydání. Praha: Management Press, 2000. 267 s., ISBN 80-7261-032-5

[5] KITA, J. Nákup a predaj. 1. vydání. Bratislava: Sprint, 1998. 194 s., ISBN 80-8884828-8

[6] KOPČAJ, A. Řízení proudu změn. 1. vydání. Ostrava: Kopčaj-Silma 90’, 1999. 298 s., ISBN 80-902358-1-6

[7] KORTSCHAK, B. H. Co je logistika (Was ist Logistik?). Přel. Černá, Š., 12. vydání. Praha: Babtext s.r.o., 1994. 127 s., ISBN 80-85816-06-7

[8] KOTLER, P., KELLER, K. L. Marketing management. Přel. Černá, Š., Faktor, V., Juppa, T., 12. vydání, Praha: Grada, 2007. 788 s., ISBN 978-80-247-1359-5

[9] KOTLER, P. Marketing od A do Z. Přel. Škapová, H., 1. vydání, Praha: Management Press 2003. 203 s., ISBN 80-7261-082-1

[10] KUHN, T. Struktura vědeckých revolucí. 1. vydání, Praha: Oikoymenh, 1997, 206 s. ISBN 80-86005-54-2

[11] LUKOSZOVÁ, X. Aktuální problémy procesního řízení nákupu v českých průmyslových podnicích. Habilitační práce, 2004

[12] LUKOSZOVÁ, X. Nákup a jeho řízení. 1. vydání, Brno: Computer Press, 2004. 120 s., ISBN 80-251-0174-6

[13] LUKOSZOVÁ, X. a kol. Řízení nákupu. 2. vydání, Ostrava: VŠB - TU Ostrava, 2000. 131 s., ISBN 80-7078-674-4

[14] LUKOSZOVÁ, X. Směry zlepšování procesů v podnikovém nákupu. Logistika, 2008, roč. 14 , č. 2 , s. $26-29$.

[15] LUKOSZOVÁ, X. Procesní řízení nákupu (1. část). Logistika, 2003, roč. 9, č. 12, s. 12-13.

[16] LUKOSZOVÁ, X. Procesní řízení nákupu (2. část). Logistika, 2004, roč. 10, č. 1, s. 13-14.

[17] LYSONS.K. Zakupy zaopatrzeniowe. Warszawa: Polskie Wydawnictwo Ekonomiczne, 2004. 504 s., ISBN 83-208-1473-1 
[18] MEFFERT, H. Marketing. Grundlagen marktorientierter Unternehmensführung. 8. Auflage. Wiesbaden: Gabler, 1998. 137 s., ISBN 3-409-69015-8

[19] PERNICA, P. Logistický management. 1. vydání. Praha: Radix, 1998. 660 s., ISBN 8086031-14-4

[20] PAVLICA, K. Sociální výzkum, podnik a management. Praha: Ekopress, 2000. 161 s., ISBN 80-86119-25-4

[21] PRAŽSKÁ, L., JINDRA, J. Obchodní podnikání. 2. přepracované vydání. Praha: Management Press, 2002. 874 s., ISBN 80-7261-059-7

[22] SCHULTE, CH. Logistika. Přel. Tomek, G., Baudyš, A., 1. vydání. Praha: Victoria Publishing, 1994. 301 s., ISBN 80-85605-87-2

[23] TOMEK, J. - HOFMAN, J. Moderní ř́zení nákupu podniku. 1. vydání. Praha: Management Press, 1999. 276 s., ISBN 80-85943-73-5

[24] TOMEK, G., TOMEK, J. Nákupní marketing. 1. vydání. Praha: Grada Publishing, 1994. 296 s., ISBN 80-85623-96-X

[25] TOMEK, G., VÁVROVÁ, V. Řízení výroby a nákupu. 1. vydání, Praha: Grada, 2007, 384 s., ISBN 978-80-247-1479-0

[26] TRUNEČEK, J. Systémy podnikového řizení ve společnosti znalostí. 1. vydání, Praha: Ediční oddělení, VŠE, 1999. 184 s. ISBN 80-7079-083-0

JEL M31

Doc. Ing. Xenie Lukoszová, Ph.D.

Katedra logistiky

Obchodně podnikatelská fakulta v Karviné

Slezská univerzita v Opavě

Univerzitní nám. 1934/3

Karviná

lukoszova@opf.slu.cz 